\title{
Potato biodiversity: A linear discriminant analysis on the nutritional and physicochemical composition of fifty genotypes
}

\author{
Shirley L. Sampaio ${ }^{\mathrm{a}, \mathrm{d}}$, João C.M. Barreira ${ }^{\mathrm{a}}$, Ângela Fernandes ${ }^{\mathrm{a}}$, Spyridon A. Petropoulos ${ }^{\mathrm{b}}$, \\ Alexios Alexopoulos $^{c}$, Celestino Santos-Buelga ${ }^{\mathrm{d}}$, Isabel C.F.R. Ferreira ${ }^{\mathrm{a}, *}$, Lillian Barros ${ }^{\mathrm{a}, *}$

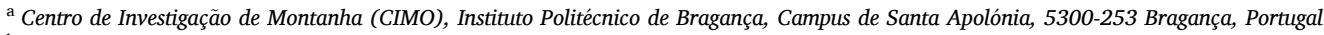 \\ ${ }^{\mathrm{b}}$ Department of Agriculture Crop Production and Rural Environment, University of Thessaly, Fytokou Street, 38446 Nea Ionia, Magnissia, Greece \\ ${ }^{\mathrm{c}}$ University of the Peloponnese, Department of Agriculture, University of Peloponnese, 24100 Kalamata, Greece \\ ${ }^{\mathrm{d}}$ Grupo de Investigación en Polifenoles (GIP-USAL), Facultad de Farmacia, Universidad de Salamanca, Campus Miguel de Unamuno s/n, 37007 Salamanca, Spain
}

\section{A R T I C L E I N F O}

\section{Keywords:}

Potato

Solanum tuberosum L.

Nutritional analysis

Physicochemical characterization

Linear discriminant analysis

Biodiversity

Food security

Chemical compounds studied in this article:

Oxalic acid (PubChem CID: 971)

Malic acid (PubChem CID: 525)

Citric acid (PubChem CID: 311)

Fructose (PubChem CID: 2723872)

Glucose (PubChem CID: 5793)

Sucrose (PubChem CID: 5988)

Trehalose (PubChem CID: 7427)

\begin{abstract}
A B S T R A C T
Fifty potato genotypes from twenty-four different countries of origin, four different flesh colours (yellow, purple, red and marble) and different cultivation types (Andean accessions, landraces, breeder lines and cultivated varieties) were studied in terms of their nutritional and physicochemical characteristics. In general, cultivated varieties and breeder lines showed the highest similarity (slight differences only in some particular fatty acids distributions: C10:0, C12:0 and C22:0) concerning the physicochemical parameters assayed in this work, independently of the geographical origin or tuber flesh colour of these genotypes. Nonetheless, some of the studied landraces and Andean accessions proved to be similar enough to be considered as genotypes with good potential for commercial cultivation. These results can contribute to the supply of new potato genotypes into sustainable farming systems, supporting the protection of potato biodiversity, particularly Andean accessions, landraces and coloured genotypes (red or purple flesh) which are not widely cultivated so far.
\end{abstract}

\section{Introduction}

Potato (Solanum tuberosum L.) is the world's most important noncereal food crop, cultivated in more than 150 countries and a staple for 1.3 billion people (Lutaladio, Ortiz, Haverkort, \& Caldiz, 2009; Narváez-Cuenca, Peña, Restrepo-Sánchez, Kushalappa, \& Mosquera, 2018; Stokstad, 2019). Its biodiversity is vast, with more than 5000 known varieties, and 200 species identified as wild (Burlingame, Mouillé, \& Charrondière, 2009). Potato is the third food crop in terms of global production after rice and wheat (Romano et al., 2018), with an annual production of about 375 million tons, covering 19.2 million hectares (ha) and an average yield of 19.5 ton/ha (FAOSTAT, 2020).

The nutritious tubers have a great potential for reducing hunger and malnutrition, and are becoming increasingly popular in developing countries, as source of nutrients and also income for their populations (International Potato Center, 2018; Narváez-Cuenca et al., 2018; Stokstad, 2019). Potato produces more calories per hectare than rice and wheat and also stands out for its efficient water use, i.e., yielding more food per unit of water than any other major crop (International Potato Center, 2018). This means that increasing the proportion of potato in human diet could help to alleviate pressure on water resources worldwide.

Most of the potatoes produced worldwide are traded in the form of raw commodity for fresh consumption as a traditional ingredient of many cuisines (Sampaio et al., 2020). Nevertheless, global consumption, particularly in developed countries, has been shifting from fresh tubers

Abbreviations: CT, cultivation type; FC, flesh colour; LDA, Linear discriminant analysis; SFA, saturated fatty acids; MUFA, monounsaturated fatty acids; PUFA, polyunsaturated fatty acids.

* Corresponding authors.

E-mail addresses: iferreira@ipb.pt (I.C.F.R. Ferreira), lillian@ipb.pt (L. Barros). 
to processed food products such as frozen potatoes, French fries, potato crisps, dehydrated potato flakes and potato flour (International Potato Center, 2018).

More than 7 million tons of factory-made French fries are produced per year worldwide (International Potato Center, 2018). In eastern Europe and Scandinavia, potato is also used in the distillation of alcoholic beverages, such as vodka and akvavit. Besides being an important staple in the human diet, tubers are also used as animal feed (Romano et al., 2018). Potato is also a rich source of starch, a functional compound widely used in a range of applications in the food and pharmaceutical industries, for instance as a stabilizer and as a carrier of substances, such as antioxidants and pharmaceutical active proteins (Wang et al., 2020).

Although potato biodiversity is vast, only a limited number of varieties are currently produced and commercialized resulting in the degradation of biodiversity and the erosion of agricultural ecosystems (Bommarco, Kleijn, \& Potts, 2013). Modern agricultural practices such as the replacement of local varieties with high-yielding species, along with climate change and environmental challenges, are contributing to the loss of potato biodiversity and thus the loss of valuable genes that encode nutrient biosynthetic pathways (Burlingame et al., 2009; Calliope, Lobo, \& Sammán, 2018). The continuous supply and introduction of new and traditional varieties into sustainable agricultural systems is a strategy to protect and increase agrobiodiversity, combat pests and diseases through tolerant or resistant genotypes, increase yields and support production in marginal lands and environments (Lutaladio et al., 2009). Moreover, the three dimensional biodiversity (ecosystems, species and within species) is essential for food security and for fighting malnutrition throughout the world (Toledo \& Burlingame, 2006).

The nutritional and physicochemical composition of potatoes depend on a number of factors, with variety being one of the most important (Burlingame et al., 2009). Several studies on the chemical composition of potatoes can be found in the literature, however the results usually relate to a limited number of genotypes, most of the time of the same area of origin. This work addresses this gap by comparing the nutritional and physicochemical characteristics of fifty potato varieties from different regions of the world. It comprises forty yellow/ white-fleshed and ten coloured-fleshed genotypes (red, purple and marble-fleshed) (Fig. 1) classified into four different cultivation types
(Andean accessions, landraces, breeder lines and cultivated varieties). This characterization study aims to make available information to stimulate the commercial use of new and/or neglected varieties, ultimately improving food and nutrition security as well as promoting potato biodiversity and the sustainable reinforcement of the biodiversity of agricultural ecosystems.

\section{Materials and methods}

\subsection{Samples}

Tubers of fifty potato genotypes were purchased from the Leibniz Institute of Plant Genetics and Crop Plant Research (IPK) (Table 1). The genotypes were selected based on the tuber flesh and/or peel colour aiming to evaluate tubers with red and purple colours. Potato powders were prepared from the fresh tubers ( 5 tubers per genotype) by handpeeling followed by freeze-drying $\left(-49^{\circ} \mathrm{C}, 0.08 \mathrm{bar}\right.$, during $48 \mathrm{~h}$, FreeZone 4.5 model 7750031, Labconco, Kansas, USA). The lyophilised samples were finally grinded into a fine powder (20 mesh) and mixed to obtain homogenized samples before analysis.

\subsection{Standards and reagents}

HPLC grade acetonitrile (99.9\%), $n$-hexane (95\%) and ethyl acetate (99.8\%) were purchased from Fisher Scientific (Lisbon, Portugal). Fatty acids methyl ester (standard 47885-U), formic acid, sugars and organic acid standards were obtained from Sigma-Aldrich (St. Louis, MO, USA). Water was treated in a Milli-Q water purification system (TGI Pure Water Systems, USA).

\subsection{Nutritional characterization and energetic value}

The contents of moisture, fat, protein, ash, carbohydrates and energy were estimated according to the Association of Official Analytical Chemists (AOAC) procedures previously followed by the authors (Sampaio et al., 2020). Briefly, the crude protein content was estimated by the macro-Kjeldahl method $(\mathrm{N} \times 6.25)$ using an automatic distillation and titration unit (model Pro-Nitro M Kjeldahl Steam Distillation System, Barcelona, Spain). Crude fat was determined by extracting the powdered sample $(3 \mathrm{~g}$ ) with petroleum ether, using a Soxhlet apparatus.

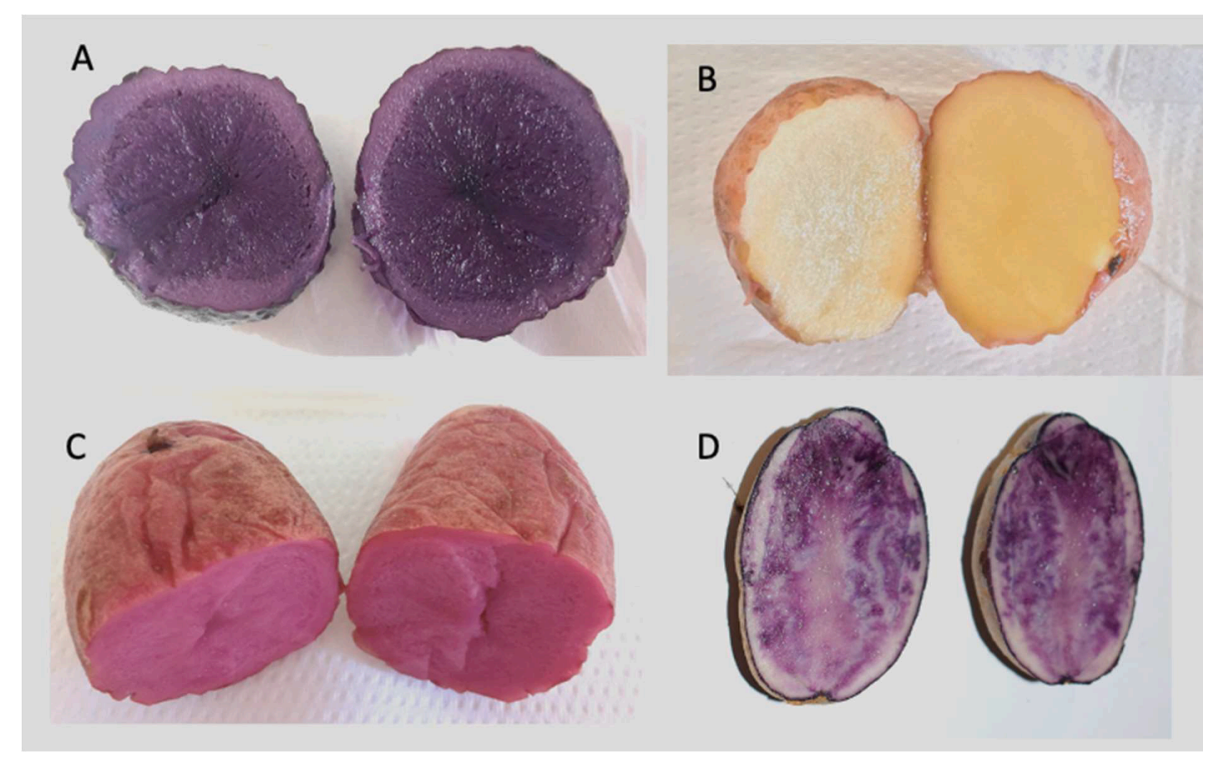

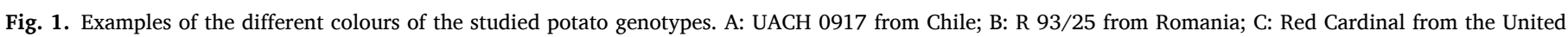

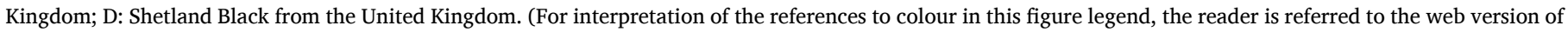
this article.) 
Table 1

Description of the fifty studied potato genotypes: variety name, country of origin, colour of the tuber flesh and cultivation type.

\begin{tabular}{|c|c|c|c|}
\hline $\begin{array}{l}\text { Variety/accession } \\
\text { name }\end{array}$ & $\begin{array}{l}\text { Country of } \\
\text { origin }\end{array}$ & $\begin{array}{l}\text { Tubers' flesh } \\
\text { colour }\end{array}$ & $\begin{array}{l}\text { Cultivation } \\
\text { type }\end{array}$ \\
\hline Royal Andes & Chile & Yellow & $\begin{array}{l}\text { Andean } \\
\text { accession }\end{array}$ \\
\hline UACH 0917 & Chile & Purple & $\begin{array}{l}\text { Andean } \\
\text { accession }\end{array}$ \\
\hline I-1039 & India & Yellow & $\begin{array}{l}\text { Andean } \\
\text { accession }\end{array}$ \\
\hline 434.1 & Peru & Yellow & $\begin{array}{l}\text { Andean } \\
\text { accession }\end{array}$ \\
\hline Desiree & $\begin{array}{l}\text { The } \\
\text { Netherlands }\end{array}$ & Yellow & $\begin{array}{l}\text { Cultivated } \\
\text { variety }\end{array}$ \\
\hline Odenwälder Blaue & Germany & Yellow & $\begin{array}{l}\text { Cultivated } \\
\text { variety }\end{array}$ \\
\hline Rosemarie & Germany & Red & $\begin{array}{l}\text { Cultivated } \\
\text { variety }\end{array}$ \\
\hline $\begin{array}{l}\text { Rote Emmalie (Red } \\
\text { Emmalie) }\end{array}$ & Germany & Red & $\begin{array}{l}\text { Cultivated } \\
\text { variety }\end{array}$ \\
\hline Violetta (Blaue Elise) & Germany & Purple & $\begin{array}{l}\text { Cultivated } \\
\text { variety }\end{array}$ \\
\hline Roswitha & Germany & Yellow & $\begin{array}{l}\text { Cultivated } \\
\text { variety }\end{array}$ \\
\hline Burmania & $\begin{array}{l}\text { The } \\
\text { Netherlands }\end{array}$ & Yellow & $\begin{array}{l}\text { Cultivated } \\
\text { variety }\end{array}$ \\
\hline Wohltmann & Germany & Yellow & $\begin{array}{l}\text { Cultivated } \\
\text { variety }\end{array}$ \\
\hline Georgian & United States & Yellow & n.a. \\
\hline Rode Eersteling & $\begin{array}{l}\text { The } \\
\text { Netherlands }\end{array}$ & Yellow & $\begin{array}{l}\text { Cultivated } \\
\text { variety }\end{array}$ \\
\hline Limba & Slovakia & Yellow & $\begin{array}{l}\text { Cultivated } \\
\text { variety }\end{array}$ \\
\hline Peredowik & Russia & Yellow & $\begin{array}{l}\text { Cultivated } \\
\text { variety }\end{array}$ \\
\hline Wiliya & Lithuania & Yellow & $\begin{array}{l}\text { Cultivated } \\
\text { variety }\end{array}$ \\
\hline Ocew & Poland & Yellow & $\begin{array}{l}\text { Cultivated } \\
\text { variety }\end{array}$ \\
\hline Rote Lötschentaler & Switzerland & Yellow & Landrace \\
\hline R 93/25 & Romania & Yellow & Breeder's line \\
\hline Shetland Blau I & United Kingdom & Yellow & Landrace \\
\hline Amyl & Czech Republic & Yellow & $\begin{array}{l}\text { Cultivated } \\
\text { variety }\end{array}$ \\
\hline Cati & Romania & Yellow & $\begin{array}{l}\text { Cultivated } \\
\text { variety }\end{array}$ \\
\hline Edzell Blue & United Kingdom & Yellow & $\begin{array}{l}\text { Cultivated } \\
\text { variety }\end{array}$ \\
\hline Gondüzo & Hungary & Yellow & $\begin{array}{l}\text { Cultivated } \\
\text { variety }\end{array}$ \\
\hline Hokkaiaka & Japan & Yellow & $\begin{array}{l}\text { Cultivated } \\
\text { variety }\end{array}$ \\
\hline Montana & Germany & Yellow & $\begin{array}{l}\text { Cultivated } \\
\text { variety }\end{array}$ \\
\hline Rosamunda & Sweden & Yellow & $\begin{array}{l}\text { Cultivated } \\
\text { variety }\end{array}$ \\
\hline Victor & Spain & Yellow & $\begin{array}{l}\text { Cultivated } \\
\text { variety }\end{array}$ \\
\hline Kefermarkter Blaue & Austria & Purple & Landrace \\
\hline P 95/115 & Uzbekistan & Yellow & Breeder's line \\
\hline Ägyptische Rote & Egypt & Yellow & n.a. \\
\hline Atzimba & Mexico & Yellow & $\begin{array}{l}\text { Cultivated } \\
\text { variety }\end{array}$ \\
\hline Early Ohio & United States & Yellow & Landrace \\
\hline Red Cardinal & United Kingdom & Red & Landrace \\
\hline Salad Blue & United Kingdom & Purple & $\begin{array}{l}\text { Cultivated } \\
\text { variety }\end{array}$ \\
\hline Tannenzapfen & Germany & Yellow & Landrace \\
\hline Teresa & Unknown & Yellow & n.a. \\
\hline Blaue aus Finnland & Finland & Purple & Landrace \\
\hline Purple & Unknown & Purple & n.a. \\
\hline Creata & $\begin{array}{l}\text { The } \\
\text { Netherlands }\end{array}$ & Yellow & $\begin{array}{l}\text { Cultivated } \\
\text { variety }\end{array}$ \\
\hline Heiderot (1977) & Germany & Yellow & $\begin{array}{l}\text { Cultivated } \\
\text { variety }\end{array}$ \\
\hline Ijsselster & & Yellow & \\
\hline
\end{tabular}

\begin{tabular}{|c|c|c|c|}
\hline $\begin{array}{l}\text { Variety/accession } \\
\text { name }\end{array}$ & $\begin{array}{l}\text { Country of } \\
\text { origin }\end{array}$ & $\begin{array}{l}\text { Tubers' flesh } \\
\text { colour }\end{array}$ & $\begin{array}{l}\text { Cultivation } \\
\text { type }\end{array}$ \\
\hline & $\begin{array}{l}\text { The } \\
\text { Netherlands }\end{array}$ & & $\begin{array}{l}\text { Cultivated } \\
\text { variety }\end{array}$ \\
\hline Lemin Punanen & Finland & Yellow & Landrace \\
\hline Norland & USA & Yellow & $\begin{array}{l}\text { Cultivated } \\
\text { variety }\end{array}$ \\
\hline Raudar Islenskar & Iceland & Yellow & Landrace \\
\hline Herd Laddie & United Kingdom & Yellow & $\begin{array}{l}\text { Cultivated } \\
\text { variety }\end{array}$ \\
\hline Shetland Black (Ellenb.) & United Kingdom & Marble & $\begin{array}{l}\text { Cultivated } \\
\text { variety }\end{array}$ \\
\hline Geiger & Unknown & Yellow & n.a. \\
\hline Emma II & Germany & Yellow & n.a. \\
\hline
\end{tabular}

na - not available information

Ash contents were determined by incineration at $550 \pm 15^{\circ} \mathrm{C}$. Total carbohydrates were calculated by difference according to the equation: $(\mathrm{g}$ per $\mathrm{kg}$ of fresh weight $(\mathrm{fw}))=100-(\mathrm{g}$ moisture $+\mathrm{g}$ fat $+\mathrm{g}$ protein + $\mathrm{g}$ ash).

Energy was calculated according to the Atwater system following the equation: $(\mathrm{kcal} / 100 \mathrm{~g} \mathrm{fw})=4 \times(\mathrm{g}$ proteins $+\mathrm{g}$ carbohydrates $)+9 \times(\mathrm{g}$ fat).

\subsection{Determination of the physicochemical features}

\subsubsection{Determination of salt content}

$\mathrm{NaCl}$ concentration was determined according to Mohr's method. The powdered samples $(1 \mathrm{~g})$ were dissolved in $20 \mathrm{~mL}$ of distilled water and filtered through a Whatman No.4 paper. The same procedure was repeated 5 times. The $\mathrm{pH}$ of the final aqueous solution was then adjusted to approximately 8.5 with sodium hydroxide, followed by the addition of $1 \mathrm{~mL}$ of a $5 \%$ potassium chromate solution. The mixture was titrated against $\mathrm{AgNO}_{3}(0.05 \mathrm{~mol} / \mathrm{L})$ until the appearance of the first reddish colour $\left(\mathrm{Ag}_{2} \mathrm{CrO}_{4}\right.$ precipitate) (Osaili et al., 2014). $\mathrm{NaCl}$ concentration was calculated using the following equation: salt content $\%=[(\mathrm{V}$ titrated of $\left.\left.\mathrm{AgNO}_{3} \times 0.00292\right)\right] /[(\mathrm{m}$ sample $)] \times 100$ (where $1 \mathrm{~mL}$ of $\mathrm{AgNO}_{3}$ corresponds to $0.00292 \mathrm{~g}$ of $\mathrm{NaCl}$ ). The results were expressed in $\mathrm{g}$ per $\mathrm{kg}$ of fw.

\subsection{2. $p H$ determination}

The $\mathrm{pH}$ of fresh tubers flesh (before lyophilisation) was measured using a calibrated digital $\mathrm{pH}$ meter (portable food and dairy $\mathrm{pH}$ meter HI 99161, Hanna Instruments, Woonsocket, RI, USA). The pH measurement was carried out in three different points of each fresh tuber.

\subsubsection{Colour assessment}

A Minolta spectrophotometer (model CR-400; Konica Minolta Sensing, Inc., Japan) was used to measure the colour in three distinct zones of the fresh potato surfaces. Using illuminant $C$ and the diaphragm opening of $8 \mathrm{~mm}$, the Hunter colour $\mathrm{L}^{*}, a^{*}$ and $b^{*}$ values were reported through the computerized system using a colour data software (Spectra Magic Nx, version CM-S100W 2.03.0006, Konica Minolta company, Japan). The instrument was calibrated with standard white tiles before analysis.

\subsubsection{Determination of organic acids}

Organic acids were determined using ultra-fast liquid chromatography (UPLC) coupled to a photodiode array detector (DAD). Samples $(\sim 2 \mathrm{~g})$ were extracted by stirring with $25 \mathrm{~mL}$ of meta-phosphoric acid $\left(4,5 \%, 25{ }^{\circ} \mathrm{C}\right.$ at $\left.150 \mathrm{rpm}\right)$ for $45 \mathrm{~min}$ and subsequently filtered (Whatman No. 4 filter). Before analysis, samples were filtered through $0.2 \mu \mathrm{m}$ nylon filters. Separation was performed with a SphereClone (Phenomenex, Torrance, CA, USA) reversed phase C18 column ( $5 \mu \mathrm{m}, 250 \times 4.6$ $\mathrm{mm}$ i.d.). Quantification was performed by comparison of the peak area recorded at 215 and $245 \mathrm{~nm}$ as preferred wavelength compared with 
calibration curves obtained from each standard compound (Barros et al., 2013). Results were processed using LabSolutions Multi LC-PDA software (Shimadzu Corporation, Kyoto, Japan) and expressed in $\mathrm{g}$ per $\mathrm{kg}$ of fw.

\subsubsection{Determination of free sugars}

Free sugars were determined by the method described by the authors (Barros et al., 2013). The powdered dried sample (1.0 g) was spiked with melezitose as internal standard (IS; $5 \mathrm{mg} / \mathrm{mL}$ ) and extracted with $40 \mathrm{~mL}$ of $80 \%$ aqueous ethanol at $80{ }^{\circ} \mathrm{C}$ for $30 \mathrm{~min}$. The resulting suspension was centrifuged (Centurion K24OR refrigerated centrifuge, West Sussex, $\mathrm{UK})$ at $15,000 \mathrm{~g}$ for $10 \mathrm{~min}$. The supernatant was concentrated at $60^{\circ} \mathrm{C}$ under reduced pressure and defatted three times with $10 \mathrm{~mL}$ of ethyl ether, successively. The remaining solution was concentrated by evaporation at $40{ }^{\circ} \mathrm{C}$. The solid residues were dissolved in water to a final volume of $5 \mathrm{~mL}$, and finally filtered $(0.2 \mu \mathrm{m}$ nylon filters, Whatman). The analysis was performed by high performance liquid chromatography with a refraction index detector (HPLC-RI; Knauer, Smartline system 1000, Berlin, Germany). The mobile phase consisted of an acetonitrile:water mixture $(70: 30 \mathrm{v} / \mathrm{v})$ at a flow rate of $1 \mathrm{~mL} / \mathrm{min}$, and the injection volume was $20 \mu \mathrm{L}$. Separation was achieved using a Eurospher 100-5 NH2 column $(4.6 \times 250 \mathrm{~mm}, 5 \mu \mathrm{m}$, Knauer). The results were recorded and processed using Clarity 2.4 software (DataApex, Prague, Czech Republic) and expressed in $\mathrm{g}$ per kg of fw.

\subsubsection{Determination of fatty acids}

Fatty acids were determined by gas-liquid chromatography with flame ionization detection (GC-FID), after the following trans-esterification procedure: fatty acids were methylated with $5 \mathrm{~mL}$ of methanol: sulphuric acid:toluene 2:1:1 (v:v:v), during at least $12 \mathrm{~h}$ in a bath at $50{ }^{\circ} \mathrm{C}$ and $160 \mathrm{rpm}$; then $3 \mathrm{~mL}$ of deionized water were added, to obtain phase separation; the fatty acid methyl esters (FAME) were recovered with $3 \mathrm{~mL}$ of diethyl ether by shaking in vortex, and the upper phase was passed through a micro-column of sodium sulphate anhydrous, in order to eliminate the water; the sample was recovered in a vial with Teflon, and before injection the sample was filtered with $0.2 \mu \mathrm{m}$ nylon filter from Milipore (Barros et al., 2013). The analysis was carried out with a DANI model GC 1000 instrument equipped with a split/splitless injector, FID at $260{ }^{\circ} \mathrm{C}$ and a Zebron-Kame column $(30 \mathrm{~m} \times 0.25 \mathrm{~mm}$ ID $\times 0.20$ $\mu \mathrm{m} d f$, Phenomenex, Lisbon, Portugal). The oven temperature program was as follows: the initial temperature of the column was $100^{\circ} \mathrm{C}$, held for $2 \mathrm{~min}$, then a $10{ }^{\circ} \mathrm{C} / \mathrm{min}$ ramp to $140{ }^{\circ} \mathrm{C}, 3^{\circ} \mathrm{C} / \mathrm{min}$ ramp to $190{ }^{\circ} \mathrm{C}$, $30{ }^{\circ} \mathrm{C} / \mathrm{min}$ ramp to $260{ }^{\circ} \mathrm{C}$ and held for $2 \mathrm{~min}$. The flow-rate of the carrier gas (hydrogen) was $1.1 \mathrm{~mL} / \mathrm{min}$, measured at $100{ }^{\circ} \mathrm{C}$. Split injection (1:50) was carried out at $250{ }^{\circ} \mathrm{C}$. FAMEs were identified by comparing their retention time with standards, and results were processed using Clarity 4.0 software (DataApex, Podohradska, Czech Republic) and expressed in relative percentage of each fatty acid.

\subsection{Statistical analysis}

For each potato variety, three independent batch samples were used, and each sample was analysed in triplicate for every single laboratorial assay. Results are expressed as mean \pm standard deviation (SD).

An analysis of variance (ANOVA) was performed employing Tukey's HSD test (homoscedastic distributions) or Tamhane's T2 test (heteroscedastic distributions) to classify the statistical differences among potatoes accessions for each of the assayed parameters. The fulfilment of the one-way ANOVA requirements, specifically the normal distribution of the residuals and the homogeneity of variance, was tested by means of the Shapiro Wilk's and the Levene's tests, respectively.

Linear discriminant analysis (LDA) was further used to identify the variables that characterized mostly each potato flesh colour (FC) or cultivation type (CT). A stepwise technique was applied, based on the Wilks' $\Lambda$ test with the usual probabilities of $F$ (3.84 to enter and 2.71 to be removed) for variable selection (Petropoulos et al., 2016). This procedure combines a series of forward selection and backward elimination steps, which verifies the significance of all previously included variables before adding an additional one as having discriminant ability. In this specific case, the basic purpose of the LDA was to characterize the relationship between a single categorical dependent variable (FC or CT) and the set of quantitative independent variables (all assayed parameters) to check for similarities in the potato genotypes, particularly in what concerns CT, as this may indicate specific non-cultivated genotypes to be used as alternative to cultivated ones. Through this method, it is possible to determine which of the independent variables contributed more to the differences in the average score profiles of the acorns belonging to FC or CT. To verify the significance of the canonical discriminating functions, Wilk's $\Lambda$ test was used. A leaving-one-out cross validation procedure was carried out to assess the model performance.

All the mentioned statistical tests were performed considering $\alpha=$ 0.05, using the Statistical Package for Social Sciences (SPSS), v. 25.0 (IBM Corp., Armonk, NY, USA).

\section{Results and discussion}

\subsection{Nutritional characterization}

The results obtained for the nutritional profile of the assayed samples are indicated in Table 2. In general, the profiles were similar, independently of flesh colour (FC) or cultivation type (CT). In the case of CT, the only variables with significant differences were fat (higher in landraces), protein (higher in Andean accessions) and ash (higher in landraces), nonetheless without significantly changing $(p=0.506)$ the energy value. Likewise, fat (higher concentrations in purple accessions) and ash (higher concentrations in red accessions) were the only nutritional parameters with significant differences among different FC. The energy and carbohydrates content remained unchanged in all the studied FC and CT.

Considering all the studied fresh potato samples, moisture content ranged from 72.4 to $74.5 \mathrm{~g} / 100 \mathrm{~g}$ fw between the different cultivation types and from 74.5 to 76.6 when the genotypes were grouped based on their tuber flesh colour. Similar values, although within a wider range (70.36 to $81.97 \mathrm{~g} / 100 \mathrm{~g} \mathrm{fw}$ ), were reported by Calliope et al. (2018) for potato varieties from the Andean region grown in South America. Burlingame et al. (2009), in their turn, determined moisture values in a still higher range (62.68-87.0 $\mathrm{g} / 100 \mathrm{~g} \mathrm{fw})$, which can be explained by the great number of varieties comprised in their literature review study on the chemical composition of potatoes. Moreover, according to Zhou, Plauborg, Kristensen, \& Andersen (2017) dry mater production is correlated with the nitrogen application regimes and the mean air temperature during the stage between the end of tuber formation initiation and maturity. In the same context, Petropoulos et al. (2020) reported that nitrogen application rates may affect dry matter allocation in plant parts (shoots, leaves and tubers) in a genotype dependent manner. Therefore, differences in the moisture (or dry matter) content among the studies could be partly attributed to differences in growing conditions and fertilization practices.

Potato is not considered a rich source of protein, therefore its content was expected to be low, and this was confirmed by the results found in our study (from 1.8 to $2.1 \mathrm{~g} / 100 \mathrm{~g}$ fw among the cultivation types and from 1.9 to $2.0 \mathrm{~g} / 100 \mathrm{~g} \mathrm{fw}$ among the different flesh colours). Vaitkevičiene (2019) reported similar values for protein content in the flesh of coloured potato varieties (an average of $2.12 \mathrm{~g} / 100 \mathrm{~g} \mathrm{fw}$ ). On the other hand, Calliope et al. (2018), Burlingame et al. (2009) and Petropoulos et al. (2020) reported slightly wider ranges (from 1.93 to $4.85 \mathrm{~g} / 100 \mathrm{~g} \mathrm{fw}, 0.85-4.2 \mathrm{~g} / 100 \mathrm{~g}$ fw and 1.4-2.6 g/100 g fw, respectively) which could be explained by differences in the factors that affect dry matter production, as mentioned before (growing conditions and nitrogen fertilization regime).

Ash content varied between 0.8 and $1.1 \mathrm{~g} / 100 \mathrm{~g}$ fw and 0.9 and 1.3 $\mathrm{g} / 100 \mathrm{~g} \mathrm{fw}$ for the different cultivation types and flesh colours, 
Table 2

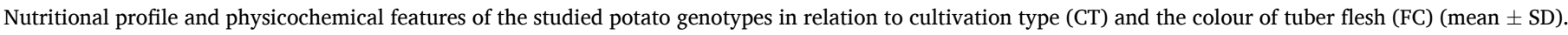

\begin{tabular}{|c|c|c|c|c|c|c|c|c|c|c|c|}
\hline & $\begin{array}{l}\text { Moisture (g/ } \\
\text { kg fw) }\end{array}$ & $\begin{array}{l}\text { Fat (g/ } \\
\text { kg fw) }\end{array}$ & $\begin{array}{l}\text { Protein (g/ } \\
\text { kg fw) }\end{array}$ & $\begin{array}{l}\text { Ash (g/ } \\
\mathrm{kg} \mathrm{fw})\end{array}$ & $\begin{array}{l}\text { Total carbohydrates } \\
(g / k g \text { fw })\end{array}$ & $\begin{array}{l}\text { Energy } \\
\text { (kcal/100 g } \\
\text { fw) }\end{array}$ & $\begin{array}{l}\text { Salt (g/ } \\
\text { kg fw) }\end{array}$ & $L^{*}$ & $a^{*}$ & $b^{*}$ & pH \\
\hline \multicolumn{12}{|c|}{ Cultivation type (CT) } \\
\hline $\begin{array}{l}\text { Andean } \\
\text { accessions }\end{array}$ & $724 \pm 25$ & $\begin{array}{l}1.5 \pm \\
0.5 b\end{array}$ & $21 \pm 4 \mathrm{a}$ & $8 \pm 2 b$ & $245 \pm 29$ & $108 \pm 11$ & $\begin{array}{l}2.6 \pm 0.3 \\
a\end{array}$ & $\begin{array}{l}61 \pm \\
20 b\end{array}$ & $1 \pm 8 b$ & $26 \pm 19$ & $\begin{array}{l}6.7 \pm \\
0.4 \mathrm{a}\end{array}$ \\
\hline $\begin{array}{l}\text { Cultivated } \\
\text { varieties }\end{array}$ & $745 \pm 92$ & $\begin{array}{l}1.6 \pm \\
0.5 b\end{array}$ & $20 \pm 5 \mathrm{ab}$ & $10 \pm 3 \mathrm{ab}$ & $224 \pm 95$ & $99 \pm 37$ & $\begin{array}{l}2.1 \pm \\
0.5 b\end{array}$ & $\begin{array}{l}63 \pm \\
16 b\end{array}$ & $2 \pm 9 b$ & $34 \pm 90$ & $\begin{array}{l}6.0 \pm \\
0.5 b\end{array}$ \\
\hline Landraces & $745 \pm 92$ & $\begin{array}{l}3.2 \pm 0.5 \\
\mathrm{a}\end{array}$ & $18 \pm 2 b$ & $11 \pm 3 a$ & $224 \pm 48$ & $99 \pm 20$ & $\begin{array}{l}1.9 \pm \\
0.4 \mathrm{~b}\end{array}$ & $\begin{array}{l}55 \pm \\
20 b\end{array}$ & $6 \pm 10 \mathrm{a}$ & $19 \pm 15$ & $\begin{array}{l}5.8 \pm \\
0.1 b\end{array}$ \\
\hline Breeder lines & $743 \pm 80$ & $\begin{array}{l}1.5 \pm \\
0.4 b\end{array}$ & $20 \pm 3 \mathrm{ab}$ & $8 \pm 1 b$ & $225 \pm 69$ & $99 \pm 27$ & $\begin{array}{l}2.1 \pm \\
0.2 b\end{array}$ & $73 \pm 1 \mathrm{a}$ & $\begin{array}{l}-2 \pm \\
2 b\end{array}$ & $24 \pm 3$ & $\begin{array}{l}5.9 \pm \\
0.1 b\end{array}$ \\
\hline $\begin{array}{l}\text { Levene's } \\
\text { test }^{1}\end{array}$ & 0.152 & 0.006 & $<0.001$ & 0.002 & 0.125 & 0.126 & $<0.001$ & $<0.001$ & 0.002 & 0.568 & 0.163 \\
\hline ANOVA test $^{2}$ & 0.537 & $<0.001$ & 0.001 & $<0.001$ & 0.557 & 0.506 & $<0.001$ & $<0.001$ & $<0.001$ & 0.443 & $<0.001$ \\
\hline \multicolumn{12}{|c|}{ Tuber flesh colour (FC) } \\
\hline Yellow & $743 \pm 83$ & $\begin{array}{l}1.8 \pm \\
0.5 \mathrm{~B}\end{array}$ & $19 \pm 5$ & $9 \pm 3 \mathrm{~B}$ & $227 \pm 85$ & $100 \pm 34$ & $2.4 \pm 0.5$ & $\begin{array}{l}69 \pm 9 \\
A\end{array}$ & $\begin{array}{l}-1 \pm 2 \\
\mathrm{D}\end{array}$ & $\begin{array}{l}27 \pm 6 \\
\mathrm{~A}\end{array}$ & $\begin{array}{l}6.0 \pm \\
0.5\end{array}$ \\
\hline Purple & $749 \pm 31$ & $\begin{array}{l}2.7 \pm 0.5 \\
\mathrm{~A}\end{array}$ & $20 \pm 3$ & $9 \pm 2 B$ & $218 \pm 32$ & $98 \pm 13$ & $2.1 \pm 0.5$ & $\begin{array}{l}25 \pm 2 \\
D\end{array}$ & $13 \pm 2 B$ & $\begin{array}{l}-4 \pm 3 \\
D\end{array}$ & $\begin{array}{l}6.0 \pm \\
0.5\end{array}$ \\
\hline Red & $766 \pm 19$ & $\begin{array}{l}1.9 \pm \\
0.5 \mathrm{~B}\end{array}$ & $20 \pm 2$ & $13 \pm 1 \mathrm{~A}$ & $200 \pm 19$ & $90 \pm 8$ & $2.3 \pm 0.3$ & $37 \pm 2 \mathrm{C}$ & $\begin{array}{l}31 \pm 2 \\
\mathrm{~A}\end{array}$ & $3 \pm 3 C$ & $\begin{array}{l}5.9 \pm \\
0.1\end{array}$ \\
\hline Marble & $764 \pm 8$ & $\begin{array}{l}2.5 \pm 0.2 \\
\mathrm{AB}\end{array}$ & $20 \pm 1$ & $9 \pm 1 \mathrm{~B}$ & $204 \pm 8$ & $92 \pm 3$ & $2.1 \pm 0.2$ & $57 \pm 2 B$ & $5 \pm 1 C$ & $17 \pm 1 \mathrm{~B}$ & $\begin{array}{l}5.8 \pm \\
0.1\end{array}$ \\
\hline $\begin{array}{l}\text { Levene's } \\
\text { test }^{1}\end{array}$ & 0.006 & $<0.001$ & $<0.001$ & $<0.001$ & 0.007 & 0.009 & 0.314 & $<0.001$ & $<0.001$ & $<0.001$ & 0.065 \\
\hline ANOVA test ${ }^{2}$ & 0.374 & $<0.001$ & 0.575 & $<0.001$ & 0.272 & 0.309 & 0.816 & $<0.001$ & $<0.001$ & $<0.001$ & 0.779 \\
\hline
\end{tabular}

Small case letters identify parameters with significant differences among different CT. Upper case letters identify parameters with significant differences among different FC.

${ }^{1} p$-values $<0.050$ indicate heteroscedastic distributions; $p$-values greater than 0.050 indicate homoscedastic distributions.

2 The indicated p-values were obtained from Tukey's HSD test in the case of homoscedastic distributions or Tamhane's T2, in the case of heteroscedastic distributions.

respectively. Similar results for ash content were found by Calliope et al. (2018) (from 0.95 to $1.73 \mathrm{~g} / 100 \mathrm{~g} \mathrm{fw}$ ). The observed differences in the ash content of the studied potatoes could be explained by the effect that factors such as climate, altitude and $\mathrm{pH}$ soil may have on dry matter allocation and the mineral composition of tubers.

Carbohydrates were the main macronutrients in concentrations, which varied from 22.0 to $24.5 \mathrm{~g} / 100 \mathrm{~g}$ fw and 20.0 to $22.7 \mathrm{~g} / 100 \mathrm{~g}$ fw (different CT and FC, respectively). In contrast, Calliope et al. (2018) and Petropoulos et al. (2020) found a wider range of usable carbohydrates (11.87 to $24.00 \mathrm{~g} / 100 \mathrm{~g}$ fw and 14.87 to $22.12 \mathrm{~g} / 100 \mathrm{~g} \mathrm{fw}$, respectively). Lipid content was very low, with values ranging from 0.15 to $0.32 \mathrm{~g} / 100 \mathrm{~g}$ fw and 0.18 to $0.27 \mathrm{~g} / 100 \mathrm{~g}$ fw (different CT and FC, respectively), whereas slightly higher ranges were reported by Burlingame et al. (2009) (0.05-0.51 g/100 g fw) and Petropoulos et al. (2020) ( 0.06 to $0.31 \mathrm{~g} / 100 \mathrm{~g} \mathrm{fw})$. Finally, energy content ranged from 99 to 108 Kcal/ $100 \mathrm{~g} \mathrm{fw}$ and from 90 to 100 , when considering the different cultivation types and tuber flesh colour, respectively, whereas Burlingame et al. (2009) reported a wider range among the tested Andean potatoes (57-100 kcal/100 g fw).

\subsection{Physicochemical parameters}

The results for salt $(\mathrm{NaCl})$ content, colour parameters and $\mathrm{pH}$ are presented in Table 2. The Andean accessions presented significantly higher values of salt content $(2.6 \mathrm{~g} / \mathrm{kg} \mathrm{fw})$ than the other studied CT (1.9-2.1 g/kg fw). Nevertheless, there was no significant difference between the four tuber colours (FC) for $\mathrm{NaCl}$ concentration (values ranged between 2.1 and $2.4 \mathrm{~g} / \mathrm{kg} \mathrm{fw}$ ). The same trend was found for the $\mathrm{pH}$ values, as only the Andean accessions presented significantly higher $\mathrm{pH}$ values (mean 6.7) than the other CT (5.8-6.0), and no significant difference was found among the studied FC (values ranged between 5.8 and 6.0). With exception of the Andean accessions, the $\mathrm{pH}$ values found in this study $(5.8-6.0)$ are in agreement with those reported by Romano et al. (2018) (5.42 -6.25) who evaluated twenty-one commercial potato varieties grown in Italy. Similarly, Feltran, Lemos, \& Vieites (2004) found values between 5.16 and 5.94 for various potato cultivars with large sized tubers cultivated in Brazil, while Yang \& Achaerandio (2015) reported higher values within the range of 5.89 and 6.00. $\mathrm{pH}$ index of pulp defines the suitable uses of tubers (table, processing, starch, universal) being negatively correlated with sugars accumulation, while values higher than 5.5 are associated with lower starch degradation due to the inactivation of phosphorylase enzyme above 5.5 values (Feltran et al., 2004).

For the quantitative colour assessment, a significant difference was found between the four FC (yellow, purple, red and marble) for all measured parameters ( $L^{*}, a^{*}$ and $\left.b^{*}\right)$, as expected. The yellow-fleshed tubers presented the highest values for $L^{*}$ (lightness) and $b^{*}$ (yellow colour), whereas the purple-fleshed tubers presented the lowest values for the same parameters. This can be associated to the qualitative lightyellow and the deep-purple colours of the flesh of the different potato genotypes (Fig. 1). In their turn, the red-fleshed tubers presented the highest $a^{*}$ values, which are associated to the red colour, while the yellow tubers had the lowest $a^{*}$. Among the different CTs, the breeder lines' tubers presented significantly higher $L^{*}$ values, associated to lighter flesh tones. Interestingly, the landraces' samples showed significantly higher $a^{*}$ values, which can be associated to a more prominent presence of red tones in tubers of this CT. According to the literature, apart from the genotypic effect on colour parameters of varieties with different flesh colour, growing conditions (location of cultivation) and cultivation system (organic $v s$ conventional farming) may also affect colour parameters in potato tuber skin and flesh (Lombardo, Pandino, \& Mauromicale, 2017; Yang \& Achaerandio, 2015).

\subsection{Organic acids}

Three organic acids were detected in the samples, namely oxalic, malic and citric acids. The results are indicated in Table 3. Citric acid was the most abundant in all FC and CT (values ranged between 5 and 8 
Table 3

Organic acids and free sugars profiles of the fifty studied potato genotypes in relation to cultivation type (CT) and the colour of tuber flesh (FC) (mean \pm SD).

\begin{tabular}{|c|c|c|c|c|c|c|c|c|c|}
\hline $\begin{array}{l}\text { Cultivation } \\
\text { type }\end{array}$ & $\begin{array}{l}\text { Oxalic acid } \\
\text { (g/kg fw) }\end{array}$ & $\begin{array}{l}\text { Malic acid } \\
\text { (g/kg fw) }\end{array}$ & $\begin{array}{l}\text { Citric acid } \\
(\mathrm{g} / \mathrm{kg} \mathrm{fw})\end{array}$ & $\begin{array}{l}\text { Total organic } \\
\text { acids }(\mathrm{g} / \mathrm{kg} \mathrm{fw})\end{array}$ & $\begin{array}{l}\text { Fructose (g/ } \\
\text { kg fw) }\end{array}$ & $\begin{array}{l}\text { Glucose (g/ } \\
\text { kg fw) }\end{array}$ & $\begin{array}{l}\text { Sucrose (g/ } \\
\mathrm{kg} \mathrm{fw})\end{array}$ & $\begin{array}{l}\text { Trehalose (g/ } \\
\text { kg fw) }\end{array}$ & $\begin{array}{l}\text { Total free sugars } \\
(\mathrm{g} / \mathrm{kg} \mathrm{fw})\end{array}$ \\
\hline $\begin{array}{l}\text { Andean } \\
\text { accessions }\end{array}$ & $1.2 \pm 0.4$ & $2.8 \pm 0.5$ & $8 \pm 1 \mathrm{a}$ & $12 \pm 1 \mathrm{a}$ & $2.0 \pm 0.4 c$ & $2 \pm 1 b$ & $2.3 \pm 0.5 \mathrm{a}$ & $0.6 \pm 0.2 \mathrm{a}$ & $7 \pm 2$ \\
\hline $\begin{array}{c}\text { Cultivated } \\
\text { varieties }\end{array}$ & $1.5 \pm 0.5$ & $2.4 \pm 0.5$ & $5 \pm 2 b c$ & $9 \pm 3 b$ & $2.5 \pm 0.4 \mathrm{ab}$ & $3 \pm 1 \mathrm{a}$ & $0.7 \pm 0.3 \mathrm{~b}$ & $0.3 \pm 0.2 b$ & $7 \pm 2$ \\
\hline Landraces & $1.2 \pm 0.5$ & $2.5 \pm 0.4$ & $5 \pm 1 c$ & $8 \pm 1 b$ & $2.3 \pm 0.3 b c$ & $3 \pm 1 \mathrm{a}$ & $0.7 \pm 0.3 \mathrm{~b}$ & $0.3 \pm 0.2 b$ & $7 \pm 2$ \\
\hline Breeder lines & $1.2 \pm 0.5$ & $2.3 \pm 0.3$ & $6 \pm 1 b$ & $9 \pm 1 b$ & $2.8 \pm 0.2 \mathrm{a}$ & $4 \pm 1 \mathrm{a}$ & $0.7 \pm 0.2 \mathrm{~b}$ & nd & $7 \pm 1$ \\
\hline Levene's test ${ }^{1}$ & $<0.001$ & $<0.001$ & $<0.001$ & $<0.001$ & $<0.001$ & $<0.001$ & $<0.001$ & $<0.001$ & $<0.001$ \\
\hline ANOVA test ${ }^{2}$ & 0.059 & 0.180 & $<0.001$ & $<0.001$ & $<0.001$ & $<0.001$ & $<0.001$ & $<0.001$ & 0.717 \\
\hline \multicolumn{10}{|c|}{ Tuber flesh colour (FC) } \\
\hline Yellow & $1.4 \pm 0.5 \mathrm{~B}$ & $2.2 \pm 0.5 \mathrm{C}$ & $5 \pm 1$ & $9 \pm 2 \mathrm{~B}$ & $2.4 \pm 0.5 \mathrm{AB}$ & $3 \pm 1 \mathrm{~B}$ & $0.8 \pm 0.5$ & $0.3 \pm 0.2 \mathrm{~B}$ & $6 \pm 1 B$ \\
\hline Purple & $0.9 \pm 0.5 \mathrm{~B}$ & $2.8 \pm 0.5 \mathrm{BC}$ & $5 \pm 1$ & $9 \pm 2 \mathrm{~B}$ & $2.8 \pm 0.5 \mathrm{~A}$ & $4 \pm 1 \mathrm{~A}$ & $0.7 \pm 0.5$ & $0.4 \pm 0.2 \mathrm{~B}$ & $8 \pm 2 \mathrm{~A}$ \\
\hline Red & $0.9 \pm 0.5 \mathrm{~B}$ & $3.8 \pm 0.3 \mathrm{~A}$ & $4 \pm 1$ & $9 \pm 2 \mathrm{~B}$ & $2.1 \pm 0.4 \mathrm{~B}$ & $3 \pm 1 \mathrm{~B}$ & $0.9 \pm 0.5$ & $0.4 \pm 0.2 \mathrm{~B}$ & $6 \pm 2 B$ \\
\hline Marble & $2.8 \pm 0.2 \mathrm{~A}$ & $3.2 \pm 0.3 \mathrm{~B}$ & $5 \pm 1$ & $11 \pm 1 \mathrm{~A}$ & $2.2 \pm 0.2 \mathrm{AB}$ & $3.1 \pm 0.3 \mathrm{~B}$ & $0.9 \pm 0.1$ & $0.6 \pm 0.2 \mathrm{~A}$ & $7 \pm 1 \mathrm{AB}$ \\
\hline Levene's test ${ }^{1}$ & $<0.001$ & $<0.001$ & $<0.001$ & $<0.001$ & 0.002 & $<0.001$ & 0.001 & $<0.001$ & 0.003 \\
\hline ANOVA test ${ }^{2}$ & $<0.001$ & $<0.001$ & 0.088 & 0.044 & 0.001 & $<0.001$ & 0.685 & 0.001 & $<0.001$ \\
\hline
\end{tabular}

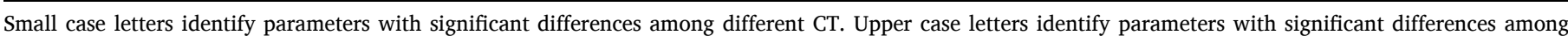
different FC.

nd $=$ not detected

1 -values $<0.050$ indicate heteroscedastic distributions; $p$-values $>0.050$ indicate homoscedastic distributions.

2 The indicated p-values were obtained from Tukey's HSD test in the case of homoscedastic distributions or Tamhane's T2, in the case of heteroscedastic distributions.

$\mathrm{g} / \mathrm{kg}$ fw and $4-5 \mathrm{~g} / \mathrm{kg}$ fw, respectively), followed by malic and oxalic acids, respectively. The Andean accessions were the richest in citric acid $(8 \mathrm{~g} / \mathrm{kg} \mathrm{fw})$ as well as in total organic acids $(12 \mathrm{~g} / \mathrm{kg} \mathrm{fw})$ content, being significantly different from the other CTs. The citric acid content of the cultivated varieties was statistically equal to landraces and breeder lines cultivation types. Among the studied FC, the marble-fleshed varieties were the richest in organic acids content $(11 \mathrm{~g} / \mathrm{kg} \mathrm{fw})$, particularly in oxalic acid $(2.8 \mathrm{~g} / \mathrm{kg} \mathrm{fw})$, while red-fleshed cultivars were the richest in malic acid $(3.8 \mathrm{~g} / \mathrm{kg} \mathrm{fw})$. The citric acid content among the four studied FC was statistically equal. Besides the organic acids detected herein (citric, malic and oxalic), Burlingame et al. (2009) and Petropoulos et al. (2020) also reported the presence of ascorbic acid in potato tubers (in concentrations of up to $42 \mathrm{mg} / 100 \mathrm{~g} \mathrm{fw}$ and $17 \mathrm{mg} / 100 \mathrm{~g}$ fw, respectively). Furthermore, earlier studies on potato tubers identified succinic, aconitic, lactic, tartaric and fumaric acid in amounts that differed among the studied cultivars (Galdón, Mesa, Elena, Rodríguez, \& Romero, 2010; Wichrowska, Rogozińska, \& Pawelzik, 2009; Yang \& Achaerandio, 2015).

\subsection{Free sugars}

Two monosaccharides, namely fructose and glucose, and two disaccharides, sucrose and trehalose, were detected in the samples. The results are presented in Table 3 . The most abundant free sugar among all CT and FC was glucose, which content was significantly higher for the purple FC and lower for the Andean accessions (400 mg/100 $\mathrm{g}$ fw and $200 \mathrm{mg} / 100 \mathrm{~g} \mathrm{fw}$, respectively). At the same time, the Andean accessions presented significantly higher values for sucrose and trehalose $(230 \mathrm{mg} / 100 \mathrm{~g} \mathrm{fw}$ and $60 \mathrm{mg} / 100 \mathrm{~g} \mathrm{fw}$, respectively) and lower amounts of fructose $(200 \mathrm{mg} / 100 \mathrm{~g} \mathrm{fw})$ than the other tested FC. The total sugars content remained almost the same among all CT, whereas the purple and marble-fleshed had the highest content among the tested FC (800 and $700 \mathrm{mg} / 100 \mathrm{~g} \mathrm{fw}$ ) without being significantly different from each other. In agreement with our findings, Plata-Guerrero, Guerra-Hernández, \& García-Villanova (2009) reported a similar profile of free sugars, where glucose was the most abundant one. In contrast, although Burlingame et al. (2009) reported the presence of glucose (15-340 mg/100 g fw), fructose $(0-180 \mathrm{mg} / 100 \mathrm{~g} \mathrm{fw})$ and sucrose $(80-1390 \mathrm{mg} / 100 \mathrm{~g} \mathrm{fw})$ in different potato varieties, sucrose was found to be the most abundant free sugar. Similarly, Petropoulos et al. (2020) reported the presence of the same three main sugars (sucrose, fructose and glucose) with sucrose being the most abundant one. This contradiction in the results was also found by Yang \& Achaerandio (2015), who also detected differences in the profile of free sugars among eight commercial cultivars. In contrast, Wegener, Jansen, \& Hans-ulrich (2009) did not observe significant differences in reducing sugars (glucose and fructose) content between two potato groups (white/yellow-fleshed and purple-fleshed), whereas sucrose content of purple-fleshed genotypes was twice than that of white/ yellow-fleshed potatoes. According to Kumar, Singh, \& Kumar (2004), apart from the genotype, several pre-harvest factors such as crop (tuber) maturity, mean air temperature during cultivation, and irrigation and fertilization management may also affect free sugars content in tubers.

\subsection{Fatty acids}

The fatty acids profiles are presented in Table 4. In total, twenty-two fatty acids were identified, however half of them in relative percentages inferior to $1 \%$. The majority of the detected fatty acids were saturated ones (SFA, 74-88\%), followed by polyunsaturated (PUFA, 11-21\%) and a small percentage of monounsaturated fatty acids (MUFA, 1.7-5.1\%). In regard to the studied CT, palmitic acid was the most abundant (C16:0; 40-48\%), followed by stearic acid (C18:0; 14-22\%) and linolenic acid (C18:2n6; 9-17\%); similar distribution was found when grouping of cultivars based on flesh colour. The Andean accessions and the coloured tubers (purple and red) were the richest in PUFA, while the yellowfleshed and breeder lines' tubers were the richest in SFA. In agreement with our study, Petropoulos et al. (2020) reported the same fatty acids as being the most abundant ones in two potato cultivars (Spunta and Kennebeq), and a similar class classification was also observed, with SFA being the most abundant type of fatty acids. In contrast, Dobson, Griffiths, Davies, \& McNicol (2004) reported linolenic acid as the most abundant fatty acid in four potato cultivars (49.2-50.2\%), followed by palmitic (18.5-20.3\%) and $\alpha$-linoleic acid (16.5-19.5\%), whereas stearic acid was detected in lower amounts (3.9-5.6\%). However, these results refer to composition at 4 weeks after harvest, and according to Yang \& Bernards (2006) wound induction after harvest may result in the formation of new fatty acids. In the same line, Camire, Kubow, \& Donelly (2009) reported that PUFA were the most abundant fatty acids class, although this report refers to cooked (baked or boiled) tubers. 
Table 4

Major fatty acids profiles ${ }^{1}$ (relative percentage) of the fifty studied potato genotypes.

\begin{tabular}{|c|c|c|c|c|c|c|c|c|c|c|c|c|c|c|}
\hline $\begin{array}{l}\text { Cultivation } \\
\text { type }\end{array}$ & C6:0 & C11:0 & C14:0 & C16:0 & C18:0 & C18:1n9 & C18:2n6 & C20:0 & C22:0 & C23:0 & C24:0 & SFA & MUFA & PUFA \\
\hline $\begin{array}{l}\text { Andean } \\
\text { accessions }\end{array}$ & $\begin{array}{l}0.7 \pm \\
0.4 \mathrm{~b}\end{array}$ & $\begin{array}{l}0.8 \pm \\
0.4 \mathrm{~b}\end{array}$ & $\begin{array}{l}1.7 \pm \\
0.5\end{array}$ & $\begin{array}{l}46 \pm 4 \\
\mathrm{ab}\end{array}$ & $14 \pm 1 c$ & $5 \pm 1 \mathrm{a}$ & $17 \pm 3 \mathrm{a}$ & $\begin{array}{l}2.6 \pm \\
0.4\end{array}$ & $\begin{array}{l}1.9 \pm \\
0.4 \mathrm{~b}\end{array}$ & $\begin{array}{l}1.6 \pm \\
0.2\end{array}$ & $\begin{array}{l}2.0 \pm \\
0.3\end{array}$ & $74 \pm 4 c$ & $5 \pm 1 \mathrm{a}$ & $\begin{array}{l}21 \pm 4 \\
\mathrm{a}\end{array}$ \\
\hline $\begin{array}{c}\text { Cultivated } \\
\text { varieties }\end{array}$ & $\begin{array}{l}1.2 \pm \\
0.5 \mathrm{~b}\end{array}$ & $3 \pm 2 \mathrm{a}$ & $\begin{array}{l}1.9 \pm \\
0.5\end{array}$ & $42 \pm 6 c$ & $\begin{array}{l}20 \pm \\
4 b\end{array}$ & $5 \pm 2 \mathrm{a}$ & $12 \pm 5 b$ & $\begin{array}{l}2.5 \pm \\
0.5\end{array}$ & $\begin{array}{l}1.8 \pm \\
0.5 \mathrm{~b}\end{array}$ & $2 \pm 1$ & $\begin{array}{l}2.2 \pm \\
0.5\end{array}$ & $\begin{array}{l}81 \pm \\
8 b\end{array}$ & $5 \pm 2 \mathrm{a}$ & $\begin{array}{l}14 \pm \\
6 b\end{array}$ \\
\hline Landraces & $\begin{array}{l}2.1 \pm \\
0.5 \mathrm{a}\end{array}$ & $4 \pm 2 \mathrm{a}$ & $\begin{array}{l}2.1 \pm \\
0.5\end{array}$ & $\begin{array}{l}43 \pm 7 \\
\mathrm{bc}\end{array}$ & $\begin{array}{l}18 \pm \\
3 \mathrm{~b}\end{array}$ & $5 \pm 2 \mathrm{a}$ & $10 \pm 5 b$ & $\begin{array}{l}2.4 \pm \\
0.5\end{array}$ & $\begin{array}{l}2.2 \pm \\
0.5 \mathrm{~b}\end{array}$ & $2 \pm 1$ & $\begin{array}{l}2.1 \pm \\
0.5\end{array}$ & $\begin{array}{l}84 \pm 7 \\
a b\end{array}$ & $5 \pm 2 \mathrm{a}$ & $\begin{array}{l}11 \pm 6 \\
\text { bc }\end{array}$ \\
\hline Breeder lines & $\begin{array}{l}0.8 \pm \\
0.4 \mathrm{~b}\end{array}$ & $\begin{array}{l}3.1 \pm \\
0.5 \mathrm{a}\end{array}$ & $\begin{array}{l}1.4 \pm \\
0.4\end{array}$ & $\begin{array}{l}48 \pm 1 \\
a\end{array}$ & $\begin{array}{l}22 \pm 6 \\
a\end{array}$ & $\begin{array}{l}1.7 \pm \\
0.1 b\end{array}$ & $9 \pm 5 b$ & $\begin{array}{l}2.2 \pm \\
0.3\end{array}$ & $4 \pm 2 a$ & $\begin{array}{l}1.8 \pm \\
0.1\end{array}$ & $\begin{array}{l}2.6 \pm \\
0.5\end{array}$ & $\begin{array}{l}88 \pm 8 \\
a\end{array}$ & $\begin{array}{l}1.7 \pm \\
0.1 \mathrm{~b}\end{array}$ & $11 \pm 7 c$ \\
\hline $\begin{array}{l}\text { Levene's } \\
\text { test }^{2}\end{array}$ & $<0.001$ & $<0.001$ & 0.001 & $<0.001$ & $<0.001$ & $<0.001$ & $<0.001$ & $<0.001$ & $<0.001$ & $<0.001$ & $<0.001$ & 0.024 & 0.001 & $<0.001$ \\
\hline ANOVA test ${ }^{3}$ & $<0.001$ & $<0.001$ & 0.404 & $<0.001$ & $<0.001$ & 0.001 & $<0.001$ & 0.154 & $<0.001$ & 0.818 & 0.276 & $<0.001$ & 0.001 & $<0.001$ \\
\hline \multicolumn{15}{|c|}{ Tuber flesh colour (FC) } \\
\hline Yellow & $\begin{array}{l}1.6 \pm \\
0.5 \mathrm{~A}\end{array}$ & $5 \pm 2$ & $\begin{array}{l}2.0 \pm \\
0.5 \mathrm{~A}\end{array}$ & $42 \pm 9$ & $\begin{array}{l}20 \pm 4 \\
\mathrm{~A}\end{array}$ & $5 \pm 2$ & $11 \pm 4 \mathrm{~B}$ & $\begin{array}{l}2.2 \pm \\
0.5 \mathrm{D}\end{array}$ & $\begin{array}{l}1.8 \pm \\
0.5 \mathrm{~B}\end{array}$ & $\begin{array}{l}2.8 \pm \\
0.5\end{array}$ & $\begin{array}{l}2.0 \pm \\
0.5 \mathrm{~B}\end{array}$ & $\begin{array}{l}83 \pm 8 \\
A\end{array}$ & $5 \pm 2$ & $\begin{array}{l}12 \pm \\
5 \mathrm{~B}\end{array}$ \\
\hline Purple & $\begin{array}{l}0.5 \pm \\
0.3 \mathrm{~B}\end{array}$ & $\begin{array}{l}0.4 \pm \\
0.2\end{array}$ & $\begin{array}{l}1.3 \pm \\
0.5 \mathrm{~B}\end{array}$ & $47 \pm 6$ & $\begin{array}{l}15 \pm \\
2 B\end{array}$ & $4 \pm 1$ & $15 \pm 5 \mathrm{~A}$ & $\begin{array}{l}3.1 \pm \\
0.5 \mathrm{C}\end{array}$ & $\begin{array}{l}2.3 \pm \\
0.5 \mathrm{AB}\end{array}$ & $\begin{array}{l}1.8 \pm \\
0.5\end{array}$ & $\begin{array}{l}2.6 \pm \\
0.5 \mathrm{~A}\end{array}$ & $\begin{array}{l}77 \pm 9 \\
\mathrm{AB}\end{array}$ & $4 \pm 1$ & $\begin{array}{l}19 \pm 6 \\
\text { A }\end{array}$ \\
\hline Red & nd & nd & $\begin{array}{l}1.2 \pm \\
0.5 \mathrm{~B}\end{array}$ & $43 \pm 4$ & $\begin{array}{l}17 \pm 3 \\
\mathrm{AB}\end{array}$ & $5 \pm 1$ & $15 \pm 3 \mathrm{~A}$ & $\begin{array}{l}3.6 \pm \\
0.4 \mathrm{~B}\end{array}$ & $\begin{array}{l}2.5 \pm \\
0.4 \mathrm{~A}\end{array}$ & $\begin{array}{l}2.2 \pm \\
0.4\end{array}$ & $\begin{array}{l}2.8 \pm \\
0.4 \mathrm{~A}\end{array}$ & $\begin{array}{l}76 \pm \\
5 B\end{array}$ & $5 \pm 1$ & $\begin{array}{l}18 \pm 5 \\
A\end{array}$ \\
\hline Marble & $\begin{array}{l}0.4 \pm \\
0.1 \mathrm{~B}\end{array}$ & nd & $\begin{array}{l}1.5 \pm \\
0.1 \mathrm{~B}\end{array}$ & $40 \pm 1$ & $\begin{array}{l}19 \pm 1 \\
\mathrm{~A}\end{array}$ & $5 \pm 1$ & $\begin{array}{l}13 \pm 1 \\
\mathrm{AB}\end{array}$ & $\begin{array}{l}4.6 \pm \\
0.2 \mathrm{~A}\end{array}$ & $\begin{array}{l}2.7 \pm \\
0.2 \mathrm{~A}\end{array}$ & $\begin{array}{l}2.0 \pm \\
0.2\end{array}$ & $\begin{array}{l}2.6 \pm \\
0.2 \mathrm{~A}\end{array}$ & $\begin{array}{l}78 \pm 1 \\
\mathrm{AB}\end{array}$ & $\begin{array}{l}5.1 \pm \\
0.3\end{array}$ & $\begin{array}{l}16 \pm 1 \\
\mathrm{AB}\end{array}$ \\
\hline $\begin{array}{l}\text { Levene's } \\
\text { test }^{2}\end{array}$ & $<0.001$ & $<0.001$ & $<0.001$ & 0.323 & $<0.001$ & $<0.001$ & $<0.001$ & 0.073 & $<0.001$ & 0.180 & $<0.001$ & $<0.001$ & $<0.001$ & $<0.001$ \\
\hline ANOVA test $^{3}$ & $<0.001$ & $<0.001$ & 0.017 & 0.066 & $<0.001$ & 0.320 & $<0.001$ & $<0.001$ & 0.003 & 0.881 & $<0.001$ & $<0.001$ & 0.468 & $<0.001$ \\
\hline
\end{tabular}

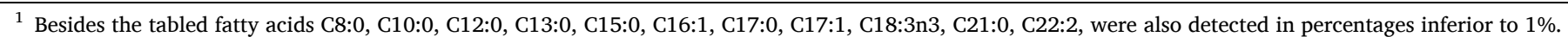

2 -values $<0.050$ indicate heteroscedastic distributions; $p$-values greater than 0.050 indicate homoscedastic distributions.

3 The indicated p-values were obtained from Tukey's HSD test in the case of homoscedastic distributions or Tamhane's T2, in the case of heteroscedastic distributions.

\subsection{Linear discriminant analysis}

Following the characterization of all individual parameters described in the former sections, the overall profiles were analysed by evaluating all differences simultaneously to verify potential linkages to the flesh colour of tubers (FC) or to the cultivation type (CT). This was achieved by linear discriminant analysis (LDA), specifically assessing the correlations among CT or FC (categorical dependent variables) and the obtained results (quantitative independent variables). The significant independent variables were selected with the stepwise method of LDA, following the Wilks' $\lambda$ test. Only variables with a statistically significant classification performance $(p<0.050)$ were maintained by the statistical model.

Starting by the effect of CT, the three defined discriminant functions included 100\% (function 1: 67.5\%; function 2: $26.7 \%$; function 3: $5.8 \%$ ) of the observed variance (Fig. 2A). Among the 48 considered variables, the discriminant model excluded only moisture, carbohydrates, total organic acids, fructose, glucose, total sugars, C14:0, C16:0, C18:1n9c, C18:3n3, C21:0, MUFA and PUFA, which indicate the lack of considerable differences for these parameter among different CT (i.e., these variables had no significant discriminant ability). In what concerns variables selected as being effectively discriminant, function 1 was mainly correlated with $\mathrm{C} 18: 2 \mathrm{n} 6 \mathrm{c}, \mathrm{pH}$ and protein content, all variables with significantly higher values among Andean accessions (markers projected on the positive side of function 1 axis), particularly when compared with landraces CT (markers projected on the farthest position taking Andean accessions as reference). Function 2, in turn, was more correlated with fat (highest content in landraces accessions) and sucrose (maximum value in Andean accessions). Considering the threedimensional placement of markers corresponding to cultivated varieties and breeder lines, as well as the small percentage explained by function 3 , it is obvious that these CT presented the highest similarities, considering all assayed parameters. Actually, the corresponding markers were only separated by function 3, mostly correlated with C22:0, C12:0 and C10:0. In this first LDA, the classification performance was $100 \%$ accurate for the original grouped cases, and $99.2 \%$, for the crossvalidated grouped ones.
In the case of $\mathrm{FC}$, the observed variation was mainly included in function 1 (function 1: 92.8\%; function 2: 5.4\%; function 3: $1.8 \%$ ), as represented in Fig. 2B. Considering that it was intended to identify the variables with highest differences, colour parameters were not included in the analysis, as these would certainly minimize the effect of all other observed results due to the inherent variability among the tested genotypes. Among the remaining 45 variables, the discriminant model excluded moisture, carbohydrates, energy, citric acid, total organic acids, fructose, glucose, C8:0, C12:0, C18:0, C18:1n9c, C22:0, SFA and PUFA, indicating that these variables had not sufficient differences to be considered as having discriminant ability. In what regards variables with significant differences among the tested FC, C21:0 showed the highest correlation with function 1, which separated yellow flesh potatoes (higher $\mathrm{C} 21: 0$ percentages) from all the other samples. Function 2, on its side, correlated mostly with C22:2, C17:1 and C16:1, separating primarily red FC from the other assayed samples. To conclude, function 3 was mostly correlated with C18:3n6, oxalic acid and C20:0, effectively separating purple and marble varieties. Overall, these last FC, which were only separated by function 3 , presenting nearly the same spatial distribution according to function 1 and function 2, presented close similarity when considering all assayed parameters together. In this second LDA, the classification performance was $100 \%$ accurate either for the original grouped cases as well as for the cross-validated grouped ones.

\section{Conclusion}

The information obtained in this study illustrates that the vast existing biodiversity of potato reflects in differences in nutrient content of tubers. Overall, and despite the apparent similarity found when analysing all parameters individually, the obtained profiles showed to be highly correlated either with different CT or with different FC. The characterized parameters highlighted the similarity among cultivated varieties and breeder lines, which showed slight variations only in some particular fatty acids, independently of the geographical origin or tuber flesh colour. This finding could be attributed to the higher breeding status and the lower heterogeneity in regard to specific characters that 

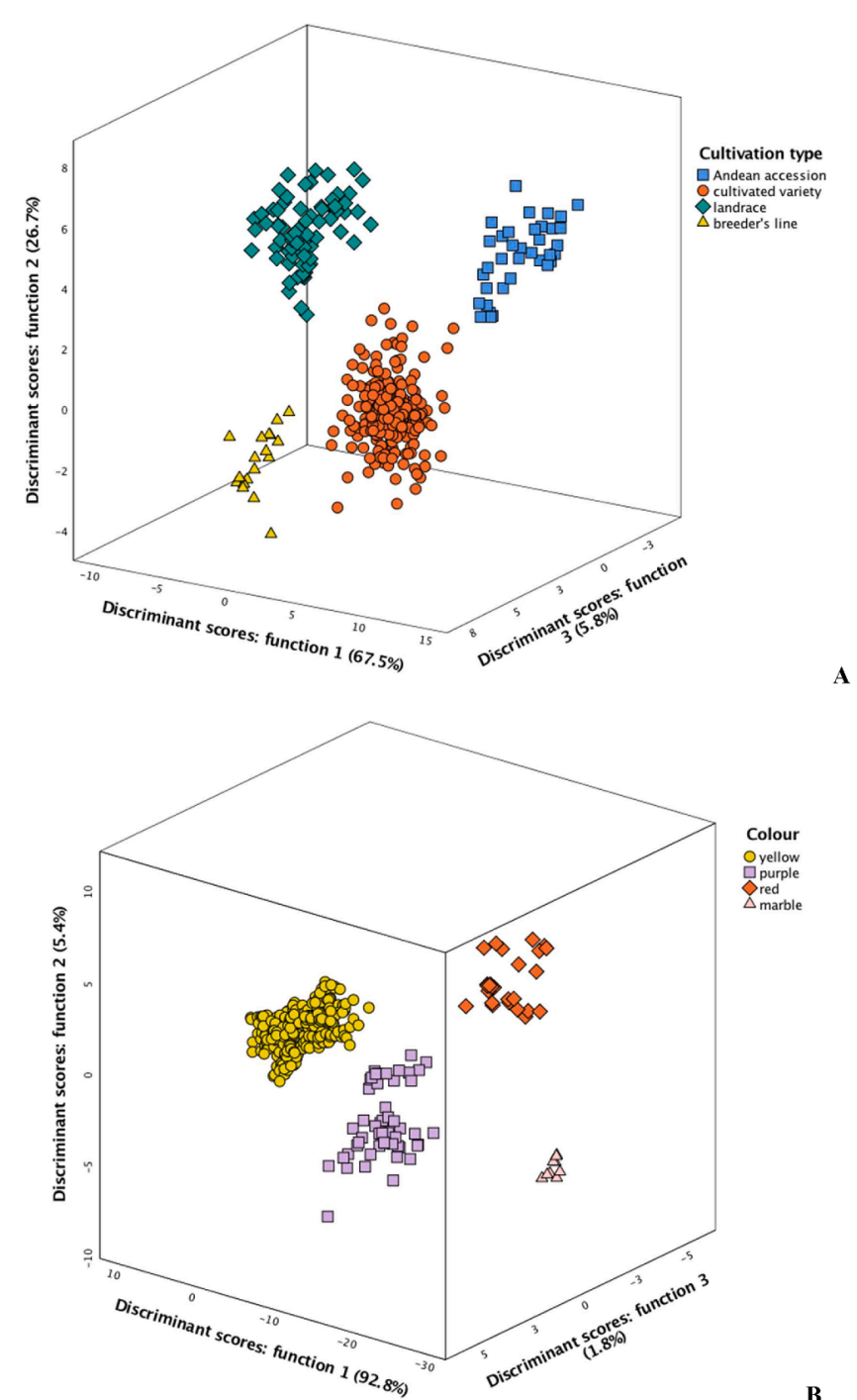

Fig. 2. (A) Spatial distribution of CT markers according to the discriminant functions coefficients. Function 1 accounted for $67.5 \%$ of the variation, function 2 accounted for $26.7 \%$, while function 3 accounted for $5.8 \%$. (B) Spatial distribution of FC markers according to the discriminant functions coefficients. Function 1 accounted for $92.8 \%$ of the variation, function 2 accounted for $5.4 \%$, while function 3 accounted for $1.8 \%$.

are appreciated by market and agronomic standards. Nonetheless, the low number of discriminant differences among these and the studied landraces and Andean accessions highlight their potential to be used as agricultural alternatives through breeding programs, especially participatory breeding where local farmers are highly involved. Bringing some of that ancient diversity back into cultivation could support potato biodiversity against environmental change, while supporting sustainable agrobiodiversity at the same time.

\section{CRediT authorship contribution statement}

Shirley L. Sampaio: Methodology, Investigation, Writing - original draft. João C.M. Barreira: Methodology, Writing - original draft. Ângela Fernandes: Methodology, Investigation. Spyridon A. Petropoulos: Methodology, Writing - review \& editing. Alexios Alexopoulos: Methodology. Celestino Santos-Buelga: Conceptualization, Methodology, Writing - review \& editing. Isabel C.F.R. Ferreira: Conceptualization, Methodology. Lillian Barros: Conceptualization, Methodology, Writing - review \& editing.

\section{Declaration of Competing Interest}

The authors declare that they have no known competing financial interests or personal relationships that could have appeared to influence the work reported in this paper.

\section{Acknowledgements}

S. Sampaio acknowledges CAPES Foundation (Ministry of Education, Brazil) for her PhD grant no. 99999.001423/2015-00. The authors are grateful to the Foundation for Science and Technology (FCT, Portugal) for financial support through national funds FCT/MCTES to CIMO (UIDB/00690/2020); the national funding by FCT, P.I., through the institutional scientific employment program-contract for L. Barros contract. GIP-USAL is financially supported by the Spanish Government through the project AGL2015-64522-C2-2-R.

\section{References}

Barros, L., Pereira, E., Calhelha, R. C., Dueñas, M., Carvalho, A. M., Santos-Buelga, C., \& Ferreira, I. C. F. R. (2013). Bioactivity and chemical characterization in hydrophilic and lipophilic compounds of Chenopodium ambrosioides L. Journal of Functional Foods, 5(4), 1732-1740. https://doi.org/10.1016/j.jff.2013.07.019.

Bommarco, R., Kleijn, D., \& Potts, S. G. (2013). Ecological intensification: Harnessing ecosystem services for food security. Trends in Ecology \& Evolution, 28(4), 230-238. https://doi.org/10.1016/j.tree.2012.10.012.

Burlingame, B., Mouillé, B., \& Charrondière, R. (2009). Nutrients, bioactive nonnutrients and anti-nutrients in potatoes. Journal of Food Composition and Analysis, 22 (6), 494-502. https://doi.org/10.1016/j.jfca.2009.09.001.

Calliope, S. R., Lobo, M. O., \& Sammán, N. C. (2018). Biodiversity of Andean potatoes: Morphological, nutritional and functional characterization. Food Chemistry, 238, 42-50. https://doi.org/10.1016/j.foodchem.2016.12.074.

Camire, M. E., Kubow, S., \& Donnelly, D. J. (2009). Potatoes and Human Health. Critical Reviews in Food Science and Nutrition, 49(10), 823-840. https://doi.org/10.1080/ 10408390903041996.

Dobson, G., Griffiths, D. W., Davies, H. V., \& McNicol, J. W. (2004). Comparison of Fatty Acid and Polar Lipid Contents of Tubers from Two Potato Species, Solanum tuberosum and Solanum phureja. J. Agric. Food Chem., 52(20), 6306-6314. https://doi.org/ 10.1021/jf049692r.

FAOSTAT. (2020). Statistical Database. Retrieved September 1, 2020, from http://www. fao.org/faostat/en/.

Feltran, J. C., Lemos, L. B., \& Vieites, R. L. (2004). Technological quality and utilization of potato tubers. Sci. agric. (Piracicaba, Braz.), 61(6), 598-603. https://doi.org/ 10.1590/S0103-90162004000600006.

Rodríguez Galdón, B., Ríos Mesa, D., Rodríguez Rodríguez, E. M., \& Díaz Romero, C. (2010). Influence of the cultivar on the organic acid and sugar composition of potatoes. Journal of the Science of Food and Agriculture, 90(13), 2301-2309. https:// doi.org/10.1002/jsfa.4086.

International Potato Center (CIP). (2018). Harnessing potato and sweetpotato's power for food security, nutrition and climate resilience; International Potato Center Annual Report 2017, 52.

Kumar, D., Singh, B. P., \& Kumar, P. (2004). An overview of the factors affecting sugar content of potatoes. Annals of Applied Biology, 145, 247-256.

Lombardo, S., Pandino, G., \& Mauromicale, G. (2017). The effect on tuber quality of an organic versus a conventional cultivation system in the early crop potato. Journal of Food Composition and Analysis, 62, 189-196.

Lutaladio, N., Ortiz, O., Haverkort, A., \& Caldiz, D. (2009). Sustainable potato production. (Food and Agriculture Organization of the United Nations, Ed.), International Year of the Potato.

Narváez-Cuenca, C. E., Peña, C., Restrepo-Sánchez, L. P., Kushalappa, A., \& Mosquera, T, (2018). Macronutrient contents of potato genotype collections in the Solanum tuberosum Group Phureja. Journal of Food Composition and Analysis, 66, 179-184.

Osaili, T. M., Al-Nabulsi, A. A., Olaimat, A. N., Shaker, R. R., Taha, M., \& Holley, R. A. (2014). Survival of Escherichia coli O157:H7 during Manufacture and Storage of White Brined Cheese. Journal of Food Science, 79, M1750-M1755.

Petropoulos, S. A., Ntatsi, G., Fernandes, Barros, L., Barreira, J. C. M., Ferreira, I. C. F. R., \& Antoniadis, V. (2016). Long-term storage effect on chemical composition, nutritional value and quality of Greek onion landrace "vatikiotiko." Food Chemistry, 201, 168-176.

Petropoulos, Spyridon A., Fernandes, Â., Polyzos, N., Antoniadis, V., Barros, L., Ferreira, C. F. R., \& I.. (2020). The Impact of fertilization regime on the crop performance and chemical composition of potato (Solanum tuberosum L.) cultivated in central Greece. Agronomy, 10, 1-18.

Plata-Guerrero, R., Guerra-Hernández, E., \& García-Villanova, B. (2009). Determination of Reducing Sugar and Asparagine in Potatoes. Journal of Liquid Chromatography and Related Technologies, 32, 2556-2568.

Romano, A., Masi, P., Aversano, R., Carucci, F., Palomba, S., \& Carputo, D. (2018), Microstructure and tuber properties of potato varieties with different genetic profiles. Food Chemistry, 239, 789-796. 
Sampaio, S. L., Fernandes, A., Pereira, C., Calhelha, R. C., Sokovic, M., Santos-Buelga, C. ... Ferreira, I. C. F. R. (2020). Nutritional value, physicochemical characterization and bioactive properties of Brazilian quinoa BRS Piabiru. Food \& Function, 11, 2969-2977.

Sampaio, S. L., Petropoulos, S. A., Alexopoulos, A., Heleno, S. A., Santos-Buelga, C., Barros, L., \& Ferreira, I. C. F. R. (2020). Potato peels as sources of functional compounds for the food industry: A review. Trends in Food Science and Technology, $103,118-129$.

Stokstad, E. (2019). The new potato. Science, 363, 574-577.

Toledo, Á., \& Burlingame, B. (2006). Biodiversity and nutrition: A common path toward global food security and sustainable development. Journal of Food Composition and Analysis, 19, 477-483.

Vaitkevičiene, N. (2019). A comparative study on proximate and mineral composition of coloured potato peel and flesh. Journal of the Science of Food and Agriculture, 99, 6227-6233.

Wang, W., Yang, Q., Ferdinand, U., Gong, X., Quc, Y., Gao, W., Ivanistau, A., Feng, B., \& Liu, M. (2020). Isolation and characterization of starch from light yellow, orange, and purple sweet potatoes. International Journal of Biological Macromolecules, 160, 660-668.

Wegener, C. B., Jansen, G., \& Hans-ulrich, J. (2009). Special quality traits of coloured potato breeding clones: Anthocyanins, soluble phenols and antioxidant capacity. Journal of the Science of Food \& Agriculture, 89, 206-215.

Wichrowska, D., Rogozińska, I., \& Pawelzik, E. (2009). Concentrations of some organic acids in potato tubers depending on weed control method, cultivar and storage conditions. Polish Journal of Environmental Studies, 18, 487-491.

Yang, W. L., \& Bernards, M. A. (2006). Wound-induced metabolism in potato (Solanum tuberosum) tubers: Biosynthesis of aliphatic domain monomers. Plant Signaling and Behavior, 1, 59-66.

Yang, Y., \& Achaerandio, I. (2015). Classification of potato cultivars to establish their processing aptitude. Journal of the Science of Food Agriculture, 96, 413-421.

Zhou, Z., Plauborg, F., Kristensen, K., \& Andersen, M. N. (2017). Dry matter production, radiation interception and radiation use efficiency of potato in response to temperature and nitrogen application regimes. Agricultural and Forest Meteorology, 232, 595-605. 